\title{
Howard, Pratt and beyond: Assessing the value of Carceral Tours as a comparative method
}

\section{Francis Pakes}

The ethics and utility of academic prison visits (also referred to as carceral tours) have been subject to heated debate for well over a decade. Perhaps the starting point of this debate was Wacquant's (2002) lament of the demise of ethnography in prisons. In this article he described a visit to the notorious Los Angeles County Jail that he described as the biggest prison in the free world along with vital statistics (23,000 inmates; budget of $\$ 1.1$ Billion). His account detailed an uncomfortable experience. He mentioned noise, filth, roaches and rats, and noticed a total lack of natural light in many spaces within the prison. Wacquant's emotions ran high: "I'm literally gasping to get my emotions under control" he says (p. 378), and felt like to should apologise to inmates: "I can't tame the nauseating feeling of being a voyeur, an intruder into this plagued space", he said (Wacquant, 2002 , p.378). He described being abhorred by how this must feel to inmates, to be on the receiving end of "the total subjection to the permanent and pervasive gaze of others" (Wacquant, 2002, p.378).

While Wacquant (2002) was uncomfortable and embarrassed on his prison excursion, some prisoner researchers, who experience prison visits from the perspective of the prisoner, are positively incensed. It is easy to see why. Minogue (2009), a long term inmate in Australia, graphically describes being on the receiving end of prison visits and recounts a series of degradations. Minogue feels humiliated as a "specimen on display" when outsiders come to visit the prison (Minogue, 2009, p48). Prison staff would point him out to visitors. Visitors observed him going to the toilet, having 'bucket baths', with open drains that were always awash with urine. Visitors were instructed not to talk with him. Other prisoner researchers such as Dey (2009) and Huckelbury (2009) share Minogue's view. Dey unequivocally states that "Tours are worthless when the officials who advocate carceral ideologies control them" (Dey, 2009, p.123). At present, they argue, prison visits at best are noninformative, usually a charade and at worst they co-opt the visitor into a dehumanizing spectacle. Piché and Walby (2010) conclude that what can be learned from prison visits, is very limited indeed and therefore offers insufficient justification for the indignities suffered by prisoners during such visits. They must stop, they argue.

On the other hand, Wilson, Spina and Canaan (2011) argue that prison visits have value, at least, for educational purposes involving university students. They researched students' attitudes after an excursion to HMP Grendon in the UK to find that such visits have the power to challenge stereotypes about prison and prisoners, findings that are expanded on by Boag and Wilson $(2013,2014)$. Wilson, 
Spina and Canaan (2011) therefore argue for the pedagogic benefit of prison visits. It must also be borne in mind that HMP Grendon, run on principles of a therapeutic community may well offer a different insight into prison than LA County Jail. For one, speaking with prisoners is part and parcel of the visit to HMP Grendon, which is rather in contrast to Wacquant's prison visit in Los Angeles and certainly in opposition to what Minogue frequently experiences in Australia.

In fact, the virtues of pedagogic visits have been praised quite regularly (e.g. Payne, Sumter and Sun, 2006). Castleberry (2007) notes the value of prison trips during which marketing and MBA students meet persons convicted of white collar crime. They argue that the accounts of these individuals helps the students consider ethical issues in their chosen field. Dellaportas and Hassall argue the same in the field of accounting. Smith, in a review argues that prison visits by students help humanize corrections and debunk myths and media stereotypes of prisons and inmates (Smith, 2012, p. 62). In their response to criticism levelled by Wilson, Spina and Canaan (2011), Piché and Walby (2012) maintain their position but do concede that ethical visits are possible but again insist on a higher degree of reflexivity than is commonly found. It is indeed important to separate prison visits with a clear educational or research objective in order to avoid what is referred to as 'dark tourism' (Lennon and Foley, 2000) where there is a focus on the consumption of violence and where there is a risk of voyeurism being the dominant motivation (Robb, 2009).

In this article I consider whether there is value in prison visits for comparative research. Could prison visits in different places offer comparative insights by revealing telling differences and similarities? Could stark differences as perceived during prison visits be indicative of meaningful differences in culture, penality, or rehabilitation? Or are prison visits simply too brief, too shallow and too scripted to have any deeper value?

This exploration is to an extent guided by my own experiences of prison visits. They are moderately varied. I have visited prisons as a sole visitor, with students and with colleagues and as part of a larger group. They have included women's prisons, remand prisons, juvenile institutions, prisons in Victorian buildings and newly built prisons. Many were one-off visits but some establishments I have visited on numerous occasions. They took place in a number of countries over three continents. I hasten to say that none of this makes me an expert. My experience does however, allow for a degree of reflexivity and of comparison. In developing the argument that prison visits do have value for the comparative researcher, my own experiences will therefore be used in illustration in conjunction with those of others. They include David Downes who compared penality in England and 
Wales and the Netherlands in the 1980s $(1982,1988)$. John Pratt's study of penal exceptionalism in the Nordic countries of Finland, Norway and Sweden also relied to a good degree on prison visits. The same can be said of Sharon Shalev's work on solitary confinement (e.g. Shalev, 2009). No doubt the biggest champion of prison visits was $18^{\text {th }}$ century penal reformer John Howard. He visited hundreds of prisons in the British Isles and the European mainland in the late $18^{\text {th }}$ and early $19^{\text {th }}$ century. His initial tours comprised the British Isles for before publishing his first book (Howard, 1777) he had already made extensive tours of the Netherlands, France and numerous other countries (see also West, 2011, for a careful appraisal of Howard's work and legacy).

My argument is that prison visits, if conducted ethically, can be a useful tool for the comparative researcher. They can inform the visitor on the immediately discernible conditions in prison: the sights, the smells, the space. They can shed light on the official stance on prisons and issues of punishment, rehabilitation, diversity and culture and how these ideologies are reproduced on the ground. During visits informal interactions can at least lift the veil to an extent on climate and relations between staff and prisoners. In addition valuable glimpses can be gained in situations where non-scripted events occur. Thus, prison visits are advisable when getting to know a penal system or a punishment culture, at an early stage. They convey valuable impressions, of how the prison presents itself and they can assist with the formulation of hypotheses on penality, culture and prison climate. That said, the prison visitor may be easily fooled.

There is no doubt that many prison tours are highly scripted. Visiting a prison is exposing you to that script. In Canada Piché and Walby (2010) discovered this through the analysis of prison tour materials that were obtained through Access to Information Requests. Prison visitors indeed see prisons metaphorically 'dressed up' through scripts and performative behaviours. These behaviours highlight certain aspects of the prison and hide others. The performative and hence, deceptive nature of the prison visit performance was not lost on John Howard (1777); "I suspect that many frauds have been concealed from me, and that sometimes the interest of my informants prevailed over their veracity" (Howard, 1777, p.5). Back then as today prisons sought to convey favourable impression on the visitor. It remains the visitor's task to see through this. In order to be able to do this it is important that layers of performance are better understood. The importance of performance in human interaction has been acknowledged many times, from Goffman (1959) onwards and it is certainly the case of prison visits. All this obscures any view on the grim realities of prison, and is likely to pander to stereotypes, so goes the argument. Let us therefore now unpick the various levels of performance. 
First there are unambiguous performances where prisoners perform an art or skill to the visitor. In my experience these have included music performances, choirs, and poetry recitals. They no doubt are intended to highlight the betterment of inmates. These are the performances that are understood as such by all involved. In addition, visitors are frequently exposed to performances in the guise of demonstrations. A classic is the use of sniffer dogs. It usually goes like this. Visitors are told about the 'the drugs problem' in prison and the lengths that inmates go through to obtain them. Enter the sniffer dog. Typical tricks performed include the dog finding drugs hidden in a visitor area or a (otherwise empty) cafeteria. The ante is occasionally upped when drugs are 'planted' on a visitor only for the dog to swiftly detect the substance. Other demonstrations may involve staff demonstrations of the use of force and restraint. Within such demonstrations visitors may be asked to take part as stooges. Such demonstrations do signify broad notions of penality and control; they seek to portray prison staff as skilled, professional and aware, all prerequisites for operating in this working environment. At the same time, prisoners are portrayed as crafty and desperate.

Less obvious and hence more interesting are the performances that are not mutually understood as such. These include the self-presentation of those who serve as hosts. The host knows that they are on show and may behave in ways that they assume is expected. All this is governed by impression management (Goffman, 1959; Leary and Kowalski, 1990) and may be more or less about reinforcing stereotypes (see Crawley, 2004) on how prison officers negotiate self-presentation, identity and emotion in prisons, an environment she describes as both emotionally charged and highly 'domestic' at the same time). There is no doubt that prisoners can be, and are, co-opted in such performances. A classic example in a local prison in the UK involved a host who casually asked a prisoner in the vicinity whether they have any advice for the visitors about prison life. The inmate swiftly quipped back: 'don't get caught!' The group smiles, so does the host and the group moves on. Such fleeting interactions obviously reveal little if anything about prison life but instead serve as an example of an inmate dutifully playing the 'role' assigned to them.

There is no doubt that visitors themselves also engage in performances. These include the asking of 'obligatory questions' about daily activities, visiting arrangements, food, and so on. Other possibly less welcome questions are about the suffering of prisoners, suicide and self-harm. The ease and eagerness with which those questions are answered may offer a glimpse beyond the script. Finally there are the systemic and symbolic performances where the interplay is between the system (mostly represented by reception and security staff) and the visitor. It involves the ID check and the depositing of items such as mobile telephones that visitors are not allowed to take into the prison. In 
some cases a visitor's photograph is taken, fingerprints may be required and a visitor badge is provided. Certainly the visitor badge is largely symbolic, if an example of what happened when I accompanied a group of students to a visit to a large prison in London is anything to go by. Due to a mix up the wrong list of names had been forwarded to the establishment. This proved no problem at all: students simply wore the pre-prepared name badges intended for a different group of students even though that meant that all names on display were incorrect. It didn't matter. While security measures are presented as an essential and non-negotiable set of rules and actions this episode highlights the essential performative and possibly vacuous nature of some of the security arrangements surrounding a prison visit: it is not so much about security per se but about communicating a message about security to the visitor. They intend to communicate to the visitor that despite the calm and professional demeanour of staff, and the occasional friendly 'banter' with prisoners this is potentially a volatile and dangerous place.

I will now sketch a number of typical constituents of prison visits. These are areas of visitor experience, prison self-presentation and various aspects that may assist the prison visitor gaining insight into what it is that they experience. These aspects are sensory experiences (of the sights, the sounds and the smells of prisons) rituals of access and security, and touring the premises with specific reference to interactions with prisoners. In discussing these I will take a more explicit comparative perspective, so that we consider these constituents as areas through which meaningful differences between countries or cultures can be established.

The first are sensory experiences. As Wacquant discovered prison visits can yield sensory experiences that can be highly distressing. John Howard (1777) certainly felt this way: he took to smelling vinegar to avoid being overcome by the stench of the many prisons he visited. He calls this frequently encountered smell "offensive beyond expression: how noxious then to people constantly confined in those prisons!" (Howard, 1777, p. 14). Howard certainly visited prisons that 'smell', but also many with a notable absence of any such odour. I have found the same both in the UK and elsewhere, so in a way, not much has changed in some 250 years. Needless to say, a stinking prison is unlikely to be a positive environment where rehabilitation is taken seriously. As such the comparative researcher is in fact well informed by simply using their nose.

You could also consider sounds. Older prisons may be characterised by the load slamming of cell doors, and the rattling and turning of keys. Sounds are particularly salient to inmates in cell. They usually cannot see into the prison from their cell so that there is a reliance on sounds to get a sense of what might be going on. Conversely, Sharon Shalev visited supermax prisons in the US and was struck by eerie quietness (Shalev, 2009, p.141). She notes the symbolic and physical distance 
between guards and prisoners, the latter portrayed as dangerous animals requiring totalitarian surveillance. The silence seems to indicate the 'accomplishment' of the total submission of the prisoners: the regime renders them both invisible and inaudible.

The second constituent is the 'stage setter'. This tends to involve a meeting in an ante-room that usually is used for meetings and training events. The establishment is frequently introduced through a Powerpoint presentation. Some vital statistics of the establishment are provided, a mission statement may be shared as well as an outline of the visit. This is the conscious part of selfpresentation that the prison engages in, which frequently is well-rehearsed and precisely scripted. A small number prepare information packs for the visitor to take away.

I have already alluded to the rituals that most visitors in most prisons go through in order to gain access and entrance to the establishment. Throughout any visit security aspects continue to be part of the script and the performance. A prison in the Far East that I visited had clearly scripted a rehabilitative theme into the visit. It involved messages about education, arts and crafts and an orientation on traditional native pursuits in language and creative work. At the same time, wherever we went our small group was preceded by about five yards by two security guards, both of whom were extremely tall and muscular and sporting stereotypical reflective sunglasses. Both supersized men walked in front of us, some two yards apart. Neither ever said a word and the distinct feeling was that speaking with these guards would be inappropriate and some violation of the script. This is a classic example of the contradictions of such establishments (see also O'Malley, 1999). The spoken message was one of rehabilitation but the unarticulated one was one of security, or worse.

In another instance, in the UK I was co-opted into a security performance. A group of about 10 students was shown round a prison and it included a brief walk through some sort of sick bay, which, we were told, was mainly filled with patients with mental health problems. I was asked to 'take the back' of the group. It was explained to us that with 'mentally disordered offenders', violence could be more volatile and unexpected. Accepting my part of the performance, I did as asked and positioned myself at the back of the group while our host led the group from the front through the corridor. The very brief episode (a matter of seconds) passed without incident. It is interesting to reflect on the meaning of this episode. My impression was that it was about the communication of dangerousness perhaps with a tinge of genuine apprehension on behalf of the host, as if to say, 'you can't be too careful when dealing with these dangerous people...'

In contrast, in a prison in Africa our group of visitors were led onto a yard where a large number of prisoners were spending time outside in the sun. Our small group (consisting of a senior member of 
prison staff, a senior police officer and two others including me) was soon surrounded by well over 100 prisoners, curious and keen to have a chat with us. This was not framed as a 'security' situation that was in any way risky at all. Regardless of whether it was or not and in my subjective experience I did not feel threatened in the slightest, the fact that the script allowed for such a situation to occur, is arguably telling: here prisoners were not portrayed as predatory animals, ready to tear apart all comers. Instead, as the conversation took place we explained who we were and why we were there. It took place in a convivial and non-threatening atmosphere.

Such interactions with prisoners comprise the most telling aspect of a prison visit. There certainly is a continuum in relation to such interactions. Although never formally forbidden to speak with prisoners I have visited high security mental health facilities where speaking with 'residents' was made structurally impossible due to the fact that the visitor would never be close enough to any person held there to achieve this. It clearly fell outside the institutional script. This is usually justified by reference to privacy. In other places speaking with prisoners was reluctantly allowed and elsewhere even positively encouraged. That has led on occasion to conversations with prisoners out of earshot of staff. On one occasion, in a women's prison in the UK, I met two Dutch inmates. I spoke with my two compatriots for some considerable time, in Dutch, our shared language. I would make the observation that a prison where visitors are forbidden or otherwise prevented from speaking with prisoners (no matter the justification) is likely to be a different prison from one where the visitor can converse with prisoners in a language that staff cannot understand. After all, it could easily be taken as conspiratorial, or as an opportunity for the prisoner to complain or convey otherwise undesirable messages. As I indicated earlier, prisoner interactions with visitors are very frequently brief and prisoners no doubt either cherry picked or self-selected. On the other hand, interactions can go beyond the performance, but only where the establishment allows for that to happen. Where it occurs it signals that the establishment is at ease with prisoners interacting with visitors. It is less worried about prisoners making the regime look bad or posing a threat. That allowance is a telling sign of difference in prison climate. At the same time it is important not to be naïve. Just because power relations are less obvious does not mean that they are not there. In fact, Shammas (2014) carefully puts these relationships under a microscope in an island prison in Norway to find many subtle expressions of power between prisoners and staff.

Often at the end there is a moment for questions and comments, as a sort of debrief. On occasion there is a lunch or so on offer. A meal in a prison offers good opportunities for establishing and appreciating difference. Do staff and prisoners eat the same food and in the same space? Do meal times offer possibilities for socialising between staff and prisoners? Such arrangements may reveal 
something about the social distance between both groups. Sharon Shalev stresses the enormous distance between guards and prisoners in US supermax prisons. I can contrast that with an experience during a prison visit in Scandinavia where prisoners and staff were dressed so similarly that for quite some time I mistook a prisoner for a staff member. We talked about the prisoner's daughter's University studies in the UK. The point is not that such conversations should be elevated to the status of 'proper' ethnography. Only to say that such experiences shed a light on difference, as a prison in which a visitor can mistake a prisoner for staff is a different place from one where you can't. The mere possibility of such a mistake strongly suggests that the social distance between staff and prisoners is much smaller and that prison dynamics are not conceptualised by the system as a case of professional keepers containing dangerous animals.

So how can such experiences fit into comparative research? Comparative research is fraught with difficulty (Pakes, 2010). In penology, there are, as there are elsewhere conceptual issues: has the term 'prison' or 'jail' the same meaning here as it has elsewhere? Are terms translatable at all (see, e.g., Nelken, 2010)? To what extent should the material conditions of prison be compared, implicitly or explicitly to conditions outside? There are issues of language, of culture, and of custom. In practical terms there is the issue of access. It seems that prison visits are more easily organised in some places than in others. In some countries prison visits may take place as part of a community engagement programme or through a link with an educational establishment. In others prison visits may be exceptional and reserved for a small number of individuals. Arguably, prison visits that provide quick, staged snap shots of establishments whose nature is particularly determined by the host to further their agenda, are perhaps least shielded from such disadvantages. With that in mind it is interesting to remember that some of the most widely read comparative works were reliant on prison visits.

This was most notably the case with John Howard. His juxtaposition of Dutch prisons with English prisons is well known. He famously said about prisons in Holland: "Prisons in the United Provinces are so quiet, and most of them so clean, that a visitor can hardly believe he is in a gaol" (Howard, 1777, p. 119). Howard was, possibly like Pratt, most concerned with the material conditions in prisons. He checked out fee structures, rules and regulations and went as far as weighing the rations of bread that prisoners received. On many occasions he comments on material conditions such as cleanliness, order, availability of water and air, meaningful activity, medical attention, official oversight, the food and so on. In France he noted that no prisoner was in irons and was told that that requires a judge's approval. This is rather in contrast to the British Isles where he found many prisoners chained in dungeons without fresh air, bathing facilities or even appropriate clothing. A 
better run prison, he surmises, does not seem to require chains. "Indeed it was evident, from the very appearance of the prisoners in most of the gaols, that humane attention was paid to them", he comments on prisons in France (Howard, 1777, p.166).

In some places Howard is explicitly comparative. "You do not hear in the streets as you pass by a prison (...) the cry of poor hungry starving debtors" he says about prisons in the Netherlands (p.45). Elsewhere he notes that 'gaol fever' simply does not seem to occur abroad whereas in the UK hundreds of inmates perished from this. He notes an absence of offensive smell ("I seldom if ever found in French prisons that offensive smell which I had often perceived in English gaols") (p. 81). He speaks of being "put to the blush" (p. 145) for his native country comparing prisons in Europe with those of England. The comparison, he says excited shame and regret in him. It highlights the explicit comparative nature of his work as well as an acknowledgement of the inherently affective nature of doing 'fieldwork' inside prisons, then and now.

Although well known, we must underscore Howard's zeal and endeavour. An aristocrat engaging in a series of hundreds of prison visits over many years to actually experience the sights and smells and speak with unfortunate individuals held in often terrible conditions remains nothing less than extraordinary. Like Elizabeth Fry after him, the drive to 'get in there', witness conditions first hand and engaging in a campaign to improve conditions in prison does set him apart from many other scholars and campaigners, like Cesare Beccaria (1767/1963), who considered punishment but without wishing to immerse themselves into the harsh realities within. To be fair, Beccaria did call for compassion and humanity to "penetrate the iron gates of dungeons" (Beccaria, 1767/1963 p.42) so was certainly not out of tune with Howard's agenda. While Beccaria's work was very widely read across Europe and the US, Cooper (1976) argued that Beccaria's theoretical work did not have any visible influence on the practical man that was John Howard.

Downes visited prisons but also conducted interviews with Dutch and English prisoners in English and Dutch prisons, a methodology repeated by Kruttschitt and Dirkzwager (2011). Pratt wrote two highly influential pieces the material from which was to a good degree derived from a series of prison visits (Pratt, 2008a, b). In Pratt and Erikson (2012) the extent of his prison visiting programme is explained. Initially, Pratt undertook 16 visits. They were a variety of prisons, lasted between two and four hours and were often followed by further discussion. Pratt and Erikson justify the method: "one of the reasons for conducting the research in this way was that it would be possible to observe recurring patterns relating to officer-inmate interaction, dining and visiting arrangements and various other accoutrements of the material conditions of life that were common across prisons and prison systems in this region" (Pratt and Erikson, 2012, p.236). They argue that: "it provides 
illustrations of what going to prison in Scandinavian countries can involve, as it was designed to do, even if not all prisons will invariably meet such conditions." It is the possibilities of prison and that would help us to consider how it is possible to think that way, about prisons and punishment. Prison visits give a definite steer as to what the parameters of possibility in penality are, the material conditions and offer a glimpse or more than a glimpse into prison culture and prison climate. Those impressions are no doubt helpful to the comparative researcher.

Howard, Downes and Pratt engaged in prison tours, rather than single prison visits. Shalev also visited more than one supermax prison in the US. That certainly allows for the establishment of difference, in scripts, performances and material conditions in a richer fashion than through single visits. A series of visits should allow for meaningful differences to be obtained in the areas that I have identified: sensory impressions, security performances, visitor-prisoners interactions, and other arrangements. It would seem that Wacquant in LA County Jail never went beyond the first two: the smells, the sounds, and the graphic visual display of prisoners as if they were animals. Despite that, Wacquant's piece, that in essence is about methodology, did not require anything else to nail the essence of LA County Jail: the absence of interactions did not prevent a powerful story to be told. It validates Paul Senior's point (2011) that you need to be aware of the structural limitations of visits as a research tool, and you need to be able to work with what you've got. Senior's point that prison visits are geographically, functionally and culturally specific is interesting as he argues that prisons are unique places. Comparative research may then be undertaken to investigate that uniqueness and place it in its social, historical, political and cultural context.

To conclude, comparative research into penality benefits from prison visits. But it is important to stress that just like with any form of research, prison visits do require an ethical consciousness. We need detailed and profound reflexivity with regards to the visit and what it means. His series of visits spurred Pratt to consider 'how it is possible to think like this' in relation to Nordic exceptionalism. Downes' sense of difference between England and Wales and the Netherlands was sharpened through prison visits and the differing accounts presented by those prisoners who had experienced both English and Dutch prisons. Howard was even able to bring profound and lasting change of prison governance in the UK further to his relentless visiting of prisons at home and abroad. As prisoner researcher Huckelbury concedes: "Prison tours are always choreographed performances, but that does not prevent perceptive participants from gaining a little insight into the operation of the physical plant they are visiting. The prison administration and its representatives naturally want to put the best face on an unpleasant situation, striving, in Sarah Palin-esque fashion, to put lipstick on a pit bull. It is therefore imperative for anyone interested in ethnographic studies of the prisoner 
demographic to look beyond the dog-and-pony show for more subtle indications of what actually transpires before they arrive and after they leave" (Huckelbury, 2009, p.126).

In a comparative setting that 'little insight' that Huckelbury speaks of can multiply into something more substantive. Clearly there are prison visits where the spectacle is one of humiliation and portrayal of prisoners as dangerous animals. In other places that far less the case and interactions with prisoners take centre stage. I have experienced prison visits with security performances as the dominating message and others where staff and prisoners mingled so freely that you needed to rely on subtle signs to distinguish between them. In yet others, such as the aforementioned prison in Asia the subliminal and the official message where in sharp contradiction. All these matters lend themselves to comparative analysis. Although, I'll acknowledge this once more, this is not a substitute for ethnography or other forms of research but to argue that how the prison presents itself to the visitor (or the outside world more broadly) is a legitimate and meaningful area of inquiry. Within that inquiry there must be reflectivity, and a broad perspective on access, entrance, sensory aspects, scripting and explicit and implicit performances. This way, we learn to appreciate difference in how prisons are presented and represented to those on the outside. And that provides input for the analysis of the implementation of penal visions that dominate our world today as well as the notable exceptions to those.

Beccaria, C. (1767/1963) On crimes and punishment. Cambridge: Cambridge University Press.

Boag, E. M., \& Wilson, D. (2014). Inside experience: engagement empathy and prejudice towards prisoners. Journal of Criminal Psychology, 4(1), 33-43.

Boag, E., \& Wilson, D. (2013). Does engaging with serious offenders change students' attitude and empathy toward offenders? A thematic analysis. The Journal of Forensic Psychiatry \& Psychology, 24(6), 699-712.

Castleberry, S. B. (2007). Prison field trips: Can white-collar criminals positively affect the ethical and legal behavior of marketing and MBA students?. Journal of Marketing Education, 29(1), 5-17.

Cooper, R. A. (1976). Ideas and Their Execution: English Prison Reform. Eighteenth Century Studies, 73-93. 
Crawley, E.M. (2004). Emotion and performance: prison officers and the presentation of self in prisons. Punishment \& Society, 6 (4) 411-427.

Dellaportas, S., \& Hassall, T. (2013). Experiential learning in accounting education: A prison visit. The British Accounting Review, 45(1), 24-36.

Dey, E. (2009) Prison Tours as a Research Tool in the Golden Gulag. Journal of Prisoners on Prisons, $12,119-125$.

Downes, D. (1982) The origins and consequences of Dutch penal policy since 1945: A preliminary analysis. British journal of criminology, 22, 325-362.

Downes, D. (1988) Contrasts in tolerance: Post-war penal policy in the Netherlands and England and Wales. Oxford: Clarendon Press.

Goffman, E. (1959) The presentation of self in everyday life. Garden City, NY, USA: Doubleday. Howard, J. (1777) The state of the prisons in England and Wales. London: William Eyres. Huckelbury, C. (2009) Tour de Farce. Journal of Prisoners on Prisons, 12, 126-128. Kruttschitt, C. and Dirkswager, A. (2011) Are there still Contrasts in Tolerance? Imprisonment in the Netherlands and England 20 years later. Punishment and society, 13, 283-306.

Leary, M.R. and Kowalski, R.M. (1990) Impression management: A literature review and twocomponent model. Psychological bulletin, 107, 34-47.

Lennon, J. and Foley, M. (2000) Dark tourism: The attraction of death and disaster. Londno: Continuum.

Minogue, Craig (2003) "Human Rights and life as an attraction in a correctional theme park", Journal of Prisoners on Prisons, 12: 44-57.Minogue, Craig. 2009. "The Engaged Specific Intellectual: Resisting Unethical PrisonTourism and the Hubris of the Objectifying Modality of the Universal Intellectual." Journal of Prisoners on Prison 18, 129-142.

Nelken, D. (2010) Comparative criminal justice: Making sense of difference. London: Sage. O'Malley, P. (1999) Volatile and contradictory punishment. Theoretical criminology, 3, 175-196. Pakes, F. (2010) The comparative method in globalised criminology. Australian and New Zealand Journal of Criminology, 43, 17-30.

Pakes, F. (2010) Comparative criminal justice. Cullompton: Willan.

Piché, J., \& Walby, K. (2010). Problematizing carceral tours. British Journal of Criminology, $50,570-581$. 
Piché, J., \& Walby, K. (2012). Carceral tours and the need for reflexivity: A response to Wilson, Spina and Canaan. Howard journal, 51, 411-418.

Pratt, J. (2008a) Scandinavian exceptionalism in an era of penal excess part I: The nature and roots of Scandinavian exceptionalism. British Journal of Criminology, 48, 119-137.

Pratt, J. (2008b) Scandinavian Exceptionalism in an Era of Penal Excess - Part II: Does Scandinavian Exceptionalism Have a Future? British Journal of Criminology, 48, 275-292.

Pratt, J. and Erikson, A. (2012) In defence of Scandanavian exceptionalism. In: T. Ugelvik and J. Dullum (Eds) Penal Exceptionalism?: Nordic Prison Policy and Practice. Abingdon: Routledge, 235259.

Robb, E.M. (2009) Violence and recreation: Vacationing in the realm of dark tourism. Anthropology and humanism, 34, 51-60.

Senior, P. (2011). In and out of the belly of the beast. International journal of offender therapy and comparative criminology, 55, 1015-1019.

Shalev, S. (2009). Supermax: Controlling risk through isolation. Cullompton: Willan.

Shammas, V. L. (2014). The pains of freedom: Assessing the ambiguity of Scandinavian penal exceptionalism on Norway's Prison Island. Punishment \& Society, 16, 104-123.

Smith, H. P. (2013). Reinforcing experiential learning in criminology: definitions, rationales, and missed opportunities concerning prison tours in the United States. Journal of Criminal Justice Education, 24(1), 50-67.

West, T. (2011) The curious Mr Howard. Hook,Hampshire: Waterside Press.

Wilson, D., Spina, R., \& Canaan, J. E. (2011). In praise of the carceral tour: Learning from the Grendon experience. Howard Journal of Criminal Justice, 50(4), 343-355. 